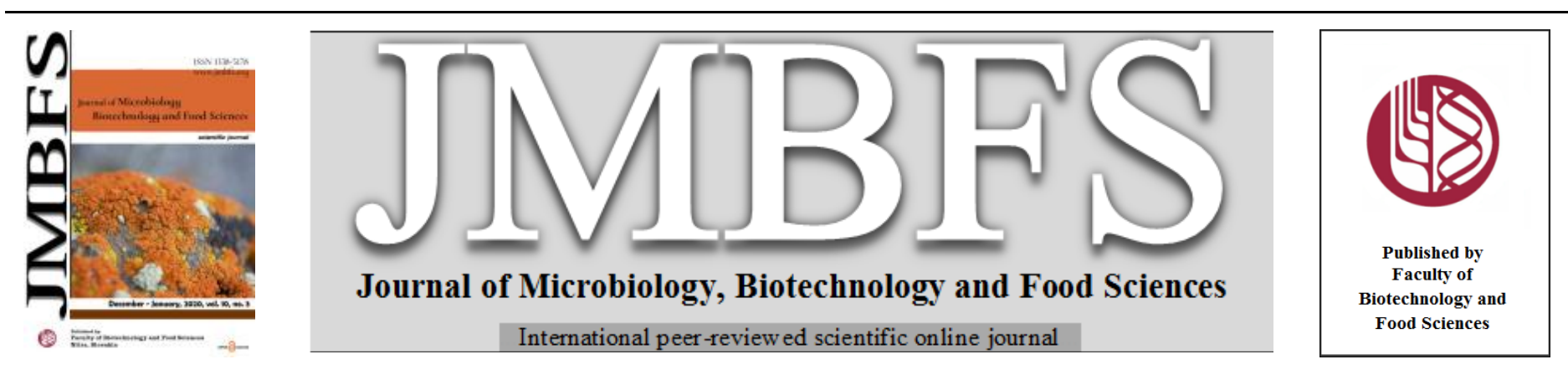

\title{
EFFICACY OF PHYTONUTRIENTS FROM POMEGRANATE PEEL ON HUMAN OVARIAN CELLS IN VITRO
}

\author{
Simona Baldovskál, Nora Maruniakovál Petr Sláma $^{2}$, Aleš Pavlík ${ }^{2}$ Ladislav Kohút ${ }^{3}$, Adriana Kolesárová* ${ }^{l}$
}

Address(es): prof. MSc. Adriana Kolesárová, PhD.,

${ }^{1}$ Slovak University of Agriculture in Nitra, Faculty of Biotechnology and Food Sciences, Department of Animal Physiology, Tr. A. Hlinku 2, 94976 Nitra, Slovak Republic, phone number: +421-37-641-4119.

${ }^{2}$ Mendel University in Brno, Faculty of AgriSciences, Department of Animal Morphology, Physiology and Genetics, Zemědělská 1/1665,

61300 Brno, Czech Republic, phone number: +420-545-133-146.

${ }^{3}$ Slovak University of Agriculture in Nitra, Faculty of Agrobiology and Food Resources, Department of Small Animal Science, Tr. A. Hlinku 2, 94976 Nitra, Slovak

Republic, phone number: +421-37-641-4319.

*Corresponding author: adriana.kolesarova@uniag.sk

doi: 10.15414/jmbfs.2020.10.3.511-516

\section{ARTICLE INFO}

Received 1.9. 2020

Revised 23. 9. 2020

Accepted 29. 10. 2020

Published 1. 12. 2020

Regular article

open $\bigodot_{\text {ACCESS }}$

\begin{abstract}
Pomegranate fruit (Punica granatum L.) is rich in antioxidants with a content of bioactive substances with high medicinal value. Punicalagin, a polyphenol from pomegranate fruit, has been studied for its antioxidant, anti-proliferative and anti-cancer activities. Ovarian cancer is one of the most common cancers in the female reproductive organs and with high rate of lethality. While it is confirmed that pomegranate has significant beneficial effects on several types of cancer, there are few detailed reports on epithelial ovarian cancer. In accordance with the potential health-promoting effects of pomegranate, the aim of our study was to examine the in vitro effect of punicalagin and pomegranate peel extract at the different concentrations $(12.5,25,50,100$, and $200 \mu \mathrm{g} / \mathrm{mL})$ for $24 \mathrm{~h}$ on the human ovarian granulosa cell line HGL5 and human ovarian carcinoma cell line OVCAR-3. For this experiment, the ethanol extract from lyophilized pomegranate peel was prepared. The metabolic activity was determined by AlamarBlue ${ }^{\mathrm{TM}}$ cell viability assay, the secretion of steroid hormones was assayed by the ELISA method. The results showed a significant $(\mathrm{P} \leq 0.001)$ decrease in the viability of HGL5 cells after the addition of the highest concentration of punicalagin $(200 \mu \mathrm{g} / \mathrm{mL})$. The number of viable OVCAR-3 cells was not significantly $(\mathrm{P} \geq 0.05)$ affected compared to the control. On the other hand, the concentrations $25,50,100$, and $200 \mu \mathrm{g} / \mathrm{mL}$ of pomegranate peel extract led to a significant decrease in the viability of OVCAR-3 cells but did not cause any significant $(\mathrm{P} \geq 0.05)$ changes in the viability of HGL5. Although our studies revealed an increase in the release of 17 $\beta$-estradiol levels by HGL5 cells after punicalagin treatment at the concentration $50(\mathrm{P} \leq 0.01)$ and $100(\mathrm{P} \leq 0.05) \mu \mathrm{g} / \mathrm{mL}$, progesterone secretion was not significantly $(\mathrm{P} \geq 0.05)$ affected. Also, the release of $17 \beta$-estradiol was significantly increased after the supplementation of pomegranate peel extract at the concentrations $50(\mathrm{P} \leq 0.01), 100$, and $200(\mathrm{P} \leq 0.001) \mu \mathrm{g} / \mathrm{mL}$. Furthermore, the levels of progesterone were significantly $(\mathrm{P} \leq 0.05)$ decreased at concentrations $12.5,25,50$, and $100 \mu \mathrm{g} / \mathrm{mL}$. In conclusion, pomegranate phytonutrients might be a promising modulator of secretion of steroid hormones and it might serve to be a potential chemoprotective agent, reducing viability of ovarian cancer cells.
\end{abstract}

Keywords: punicalagin, pomegranate, ovarian cells, steroid hormones, cancer

\section{INTRODUCTION}

Dietary phytochemicals present in fruits and vegetables exhibit many beneficial properties, including chemotherapeutic agents owing to their antitumor activity (Zhou et al., 2016). Recent studies have showed that phytonutrients such as polyphenols, flavonoids (e.g. isoquercitrin, rutin, quercetin) (Michalcova et al., 2019; Roychoudhury et al., 2018), ellagitannins (e.g. punicalagin, ellagic acid) (Packova et al., 2015, 2016), and glycosides (e.g. amygdalin) (Halenar et al., 2017; Kolesar et al., 2018; Kopcekova et al., 2018; Kovacikova et al., 2019; Kolesárová et al., 2020) may possess health-promoting effects as well as and the ability to ameliorate alterations of the reproductive system. Recently, several in vitro and in vivo experiments have revealed the beneficial physiological activities of pomegranate fruit and human studies have further indicated its promising potential as a protective agent against various diseases (Kandys and Kokkinomagoulos, 2020).

Pomegranate (Punica granatum L.) is a rich source of valuable nutritional substances, including flavonols, anthocyanins, phenolic acids, mainly gallic acid and ellagic acid, organic acids, condensed and hydrolysable tannins, especially ellagitannins such as punicalagin, punicalin, and gallotannins. These bioactive substances have been related with various beneficial properties against a number of diseases. Pomegranate peels contain a lot of phenolic compounds, minerals, and polysaccharides, while arils contain water $(85 \%)$, sugars, pectin, organic acids, phenolics, and anthocyanins. Proteins, crude fibers, vitamins, minerals, pectin, sugars, polyphenols, isoflavones, and the composition of the pomegranate seed oil is mainly linolenic and linoleic acids, lipids such as punicic acid, oleic acid, stearic acid, and palmitic acid (Viuda-Martos et al., 2010). More recently, clinical and preclinical studies have provided scientific evidence that pomegranates possess remarkable antioxidant (Singh et al., 2014), antiinflammatory (Gonzalez-Trujano et al., 2015), anti-cancer (Syed et al., 2013; Sharma et al., 2017), anti-obesity (Al-Muammar et al., 2012), and neuroprotective (Yuan et al., 2016) properties. The multiple health benefits of the pomegranates are considered mainly to be due to the presence of polyphenol punicalagin and other metabolites, such as flavonols and anthocyanins (Cerda $\boldsymbol{e t}$ al., 2003).

Punicalagin, a bioactive constituent belonging to the family of ellagitannins, is the most abundant polyphenol found in pomegranate peel with a molecular weight of $1084.71 \mathrm{~g} / \mathrm{mol}$ (Yao et al., 2017), and responsible for more than half pomegranate juice's antioxidant properties (Seeram et al., 2005). Following the digestion path, ellagitannins are converted by the intestinal flora into urolithins (Viuda-Martos et al., 2010). Punicalagin has been associated with beneficial impact to human health, including anti-oxidant (Seeram et al., 2005), antiinflammatory, cardio-protective (El-Missiry et al., 2015), neuro-protective (Yaidikar and Thakur, 2015), pro-apoptotic and anti-cancer (Zhang $\boldsymbol{e t}$ al., 2020) activities. Punic acid, kaempferol, and $\beta$-sitosterol are phytoestrogens found in pomegranates, which are structurally similar to steroid hormone $17 \beta-$ estradiol and have shown phytoestrogenic activity (Choi et al., 2006), thus reducing the hormonal effect of endogenous estrogens (Papoutsi et al., 2005). Steroid hormone $17 \beta$-estradiol, the most effective female estrogen, and its receptors (ER $\alpha$ and $E R \beta)$ play a critical role in the control of a plethora of biological responses that strongly affect several aspects of physiology, including 
risk factors for the initiation and progression of hormone-related cancers. Depending on the estrogen receptor subtypes, 17 $\beta$-estradiol exhibits divergent effects on cancer cells (Deroo and Korach, 2006)

Ovarian cancer, one of the most common malignant tumors, is the leading cause of death from gynecological cancers in women (Siegel $\boldsymbol{e t}$ al., 2018). One of the strategies is to develop novel low-toxic anti-cancer agents. Therefore, dietary products enriched by bioactive phytochemicals may be used as a potential nutritional strategy in slowing the progression of gynecological malignancy and may provide useful alternative therapeutic approaches (Zhou et al., 2016).

So far, little is known about the impact of pomegranate or punicalagin on the female reproductive system and its effect on ovarian steroidogenesis or tumorigenesis. Therefore, selected ovarian model cells were used to study antiproliferative effects in ovarian cancer and the modulation of secretion of steroid hormones, with the aim to better understand the mechanism of action of the above-mentioned phytonutrients. The immortalized human granulosa cell line HGL5 and human ovarian epithelial carcinoma cell line OVCAR-3 have been previously described (Michalcova et al., 2019; Baldovská et al., 2019).

The objective of the present study was to examine the cell viability and the secretion of selected steroid hormones after supplementation of a number of the concentrations of punicalagin and pomegranate peel extract ranging from 12.5 to $200 \mu \mathrm{g} / \mathrm{mL}$ using human ovarian cells HGL5 and OVCAR-3. Furthermore, we compared the efficacy of punicalagin and pomegranate peel extract.

\section{MATERIAL AND METHODS}

\section{Ovarian cell lines}

The human ovarian granulosa cell line HGL5 ( $\mathrm{ABM}^{\circledR}, \mathrm{BC}$, Canada) was cultured in Dulbecco's modified Eagle medium (Sigma-Aldrich, MO, USA) supplemented with $10 \%$ fetal bovine serum (Sigma-Aldrich, MO, USA), $1 \%$ antibiotics/antimycotics (Invitrogen, CA, USA), and incubated in a $5 \% \mathrm{CO}_{2}$ incubator at $37^{\circ} \mathrm{C}$.

The human ovarian carcinoma cell line OVCAR-3 was obtained from the American Type Culture Collection (ATCC ${ }^{\circledR}$, VA, USA). The cells were cultured in RPMI 1640 medium (Gibco-BRL, MD, USA) supplemented with $10 \%$ feta bovine serum (Sigma-Aldrich, MO, USA), $1 \%$ antibiotics/antimycotics (Invitrogen, CA, USA), $1 \%$ non-essential amino acids (Sigma Aldrich, UK), and incubated in a $5 \% \mathrm{CO}_{2}$ incubator at $37{ }^{\circ} \mathrm{C}$. The initial concentrations of cells before setting up the culture ranged from $10^{4}$ to $10^{5}$ cells per mL. The cells were grown in a standard T75 cell culture flask (Corning Life Sciences, NY, USA) to $80-90 \%$ confluence.

\section{Treatment for human ovarian cells}

Punicalagin (Sigma-Aldrich, St. Louis, MO, USA) and pomegranate peel extract were used in this study. For this experiment, the ethanol extract from lyophilized pomegranate peel was prepared. Prior to the experiments, pure punicalagin was dissolved in a culture medium and diluted to the desired concentrations. Depending on the treatment, the cells were cultured in plates without (control group) or with punicalagin or pomegranate peel extract at concentrations 12.5 , $25,50,100$, and $200 \mu \mathrm{g} / \mathrm{mL}$ for short-term application $(24 \mathrm{~h})$. Cells treated with ethanol in an amount corresponding to the highest used concentration of the extract were used as positive controls (+Control) for the experiments.

\section{Cell viability assay}

Cell viability was evaluated using AlamarBlue ${ }^{\mathrm{TM}}$ (BioSource International, Nivelles, Belgium) cell viability assay as a suitable indicator of cellular health and viability (Bannerman et al., 2001). Briefly, the HGL5 and OVCAR-3 cells were cultured in a 96-well plate (Grainer, Germany). $100 \mu \mathrm{L}$ of cell suspensions per well $\left(1.5 \times 10^{4}\right.$ cells per $\left.\mathrm{mL}\right)$ were seeded and grown overnight in a $5 \% \mathrm{CO}_{2}$ incubator at $37{ }^{\circ} \mathrm{C}$. After pre-incubation, the cells were grown in the culture medium without (control group) or with punicalagin/pomegranate peel extract at different concentrations. After treatment, $10 \mu \mathrm{L}$ of AlamarBlue solution was added to each well at the indicated time 4 hours before the endpoint and incubated at $37{ }^{\circ} \mathrm{C}$. The AlamarBlue reduction as a result of multiple metabolic reactions was measured spectrophotometrically. Absorbance was measured at $560 \mathrm{~nm}$ and $590 \mathrm{~nm}$ by an ELISA microplate reader (Multiskan FC, Thermo Fisher Scientific, Finland). For each experiment, wells containing only the AlamarBlue solution without cells were also prepared and incubated. The fluorescence measured in those was used as a background and subtracted. The results were expressed as the percentage of viable cells. Analyses were performed in three independent experiments with 8 replicates (culture wells per group) per experiment.

\section{ELISA (enzyme-linked immunosorbent assay)}

Concentrations of steroid hormones (17 $\beta$-estradiol and progesterone) after pure punicalagin and pomegranate peel extract treatment secreted by HGL5 were determined spectrophotometrically using ELISA kit (NOVATEC, Dietzenbach,
Germany) according to the manufacturer's instructions. Cells were re-seeded in a 24-well culture plate (Grainer, Germany) at a density of $1 \times 10^{5}$ cells per $\mathrm{mL}$ and incubated in DMEM culture media (control) or with punicalagin/pomegranate peel extract at different concentrations for $24 \mathrm{~h}$. Analyses from three independent experiments were performed with three replicates per experimental group. The level of $17 \beta$-estradiol and progesterone were measured at a wave length of 450 $\mathrm{nm}$ on an ELISA microplate reader (Thermo Scientific Multiskan FC, Vantaa, Finland). Intra-and inter-assay coefficient for $17 \beta$-estradiol was set at $\leq 9 \%$ and $\leq 10 \%$, and for progesterone at $\leq 4 \%$ and $\leq 9.3 \%$, respectively. The sensitiveness was $8.68 \mathrm{pg} / \mathrm{mL}$ for $17 \beta$-estradiol and $0.05 \mathrm{ng} / \mathrm{mL}$ for progesterone.

\section{Statistical analysis}

Analyses were performed in at least three independent experiments with replicates per experiment. All data were expressed as the mean \pm standard error of the mean (SEM). Statistical analysis was carried out using the GraphPad Prism 5 program (version 3.02 for Windows; GraphPad Software, CA, USA). One-way analysis of variance (ANOVA) along with Dunnett's test as a follow-up test to ANOVA was performed as appropriate to determine the statistical significance of differences of the data. The statistical significance was set at probability values of $\mathrm{P} \leq 0.05$.

\section{RESULTS AND DISCUSSION}

\section{Effect of punicalagin on cell viability}

To investigate the effects of punicalagin on cell viability in human ovarian cell lines, HGL5 and OVCAR-3 cells were treated with pure punicalagin at different concentrations for $24 \mathrm{~h}$. AlamarBlue cell viability assay was used to measure the number of viable cells. In this in vitro study, we observed a significant $(\mathrm{P} \leq 0.001)$ decrease of viable HGL5 cells after punicalagin treatment only at the highest concentrations of $200 \mu \mathrm{g} / \mathrm{mL}$. On the other hand, treatment with punicalagin at all the concentrations used in the study did not cause any significant changes $(\mathrm{P}>0.05)$ in the viability of human ovarian cancer cells OVCAR-3. The results are shown in Figure 1

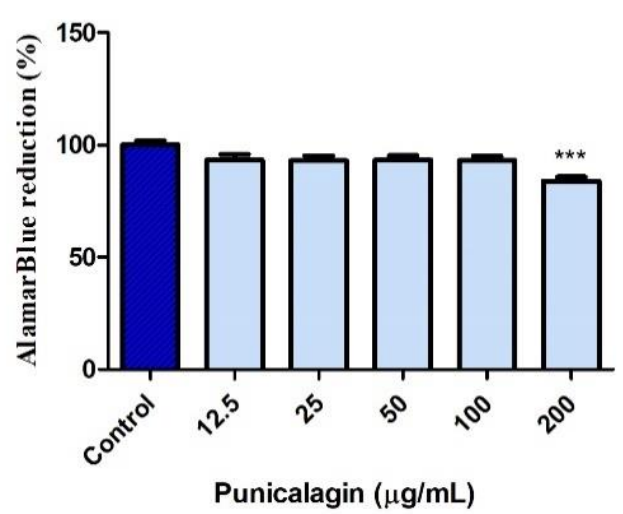

A

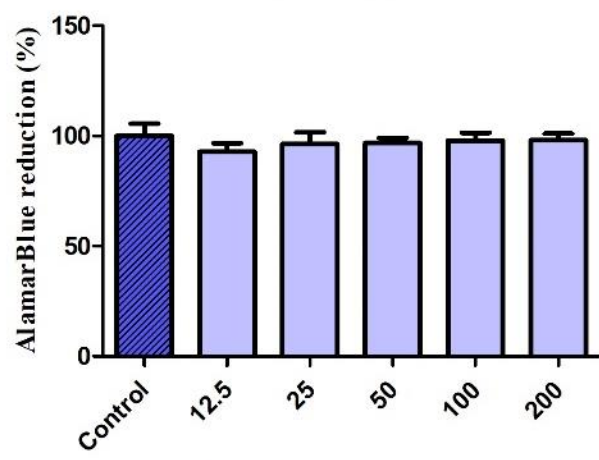

Punicalagin $(\mu \mathrm{g} / \mathrm{mL})$

B

Figure 1 Viability of human ovarian granulosa cells HGL5 (A) and human ovarian carcinoma cells OVCAR-3 (B) without (control) or with punicalagin treatment $(12.5,25,50,100$, and $200 \mu \mathrm{g} / \mathrm{mL})$ for $24 \mathrm{~h}$. The significance of differences between the groups was evaluated by One-way ANOVA followed by Dunnett's multiple comparison test. The data are expressed as means \pm SEM. AlamarBlue. 


\section{Effect of pomegranate peel extract on cell viability}

To evaluate the effects of pomegranate peel extract on the viability of human ovarian cells HGL5 and OVCAR-3, cells were treated with pomegranate peel extract at different concentrations for $24 \mathrm{~h}$. AlamarBlue cell viability assay was used to measure the number of viable cells. Our data showed a significant decrease $(\mathrm{P} \leq 0.001)$ of cell viability of OVCAR-3 cells in a dose-dependent manner at $25,50,100$, and $200 \mu \mathrm{g} / \mathrm{mL}$, but there was no effect $(\mathrm{P} \geq 0.05)$ on healthy ovarian granulosa cells. Pomegranate peel extract used in this study inhibited ovarian cancer cell proliferation in vitro but did not affect the viability of HGL5 cells, however, we observed a slight tendency of increase of viable cells at the concentrations 25, 50, and $100 \mu \mathrm{g} / \mathrm{mL}$. The results are shown in Figure 2.

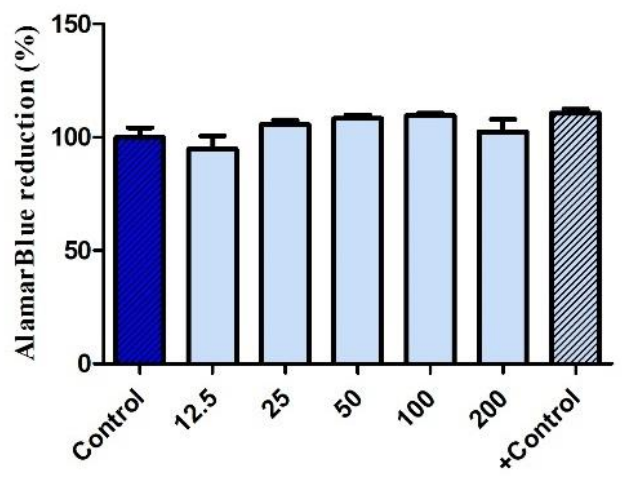

Pomegranate peel extract $(\mu \mathrm{g} / \mathrm{mL})$

$\mathbf{A}$

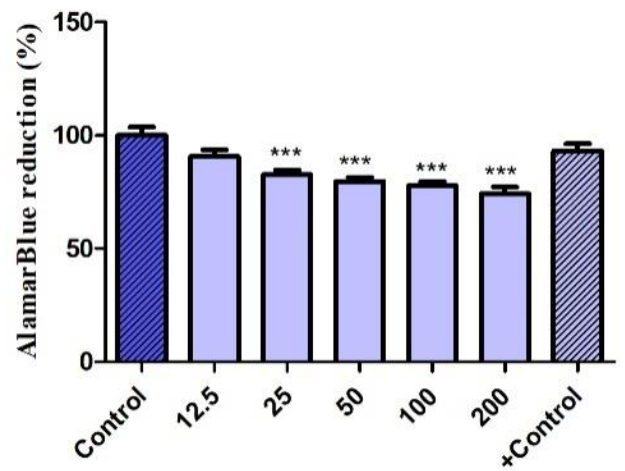

Pomegranate peel extract $(\mu \mathrm{g} / \mathrm{mL})$

Figure 2 Viability of human ovarian granulosa cells HGL5 (A) and human ovarian carcinoma cells OVCAR-3 (B) without (control) or with pomegranate peel extract treatment $(12.5,25,50,100$, and $200 \mu \mathrm{g} / \mathrm{mL})$ for $24 \mathrm{~h}$. +Control with ethanol in an amount corresponding to the highest used concentration of extract. The significance of differences between the groups was evaluated by One-way ANOVA followed by Dunnett's multiple comparison test. The data are expressed as means \pm SEM. AlamarBlue.

\section{Effect of punicalagin on the release of steroid hormones}

To further evaluate the effects of punicalagin on human ovarian cells in vitro, we measured the release of steroid hormones (Figure 3) 17 $\beta$-estradiol (A) and progesterone (B) by HGL5 cells after punicalagin treatment. Punicalagin could increase the secretion of $17 ß$-estradiol at the concentration $50(\mathrm{P} \leq 0.01)$ and 100 $(\mathrm{P} \leq 0.05) \mu \mathrm{g} / \mathrm{mL}$ by HGL5 cells. However, no concentration of punicalagin used in this study affected $(\mathrm{P} \geq 0.05)$ the progesterone secretion in comparison to control.

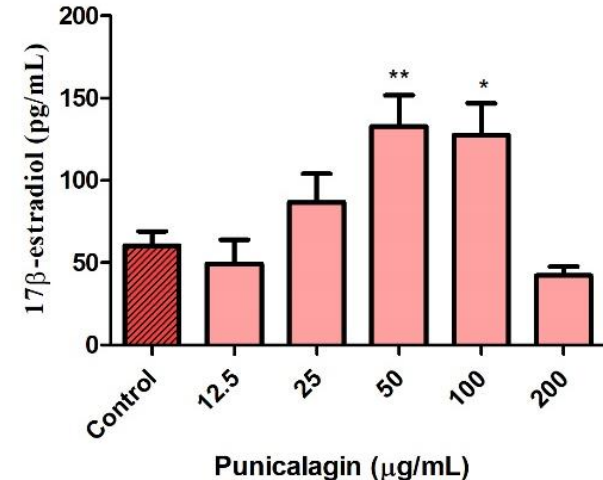

A

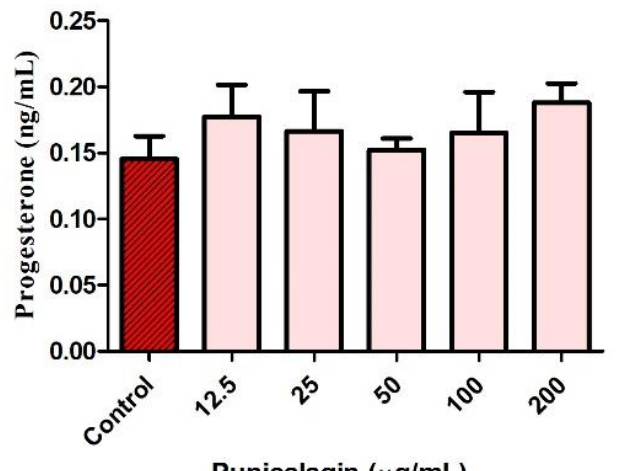

Figure 3 Release of $17 \beta$-estradiol (A) and progesterone (B) by HGL5 cells after treatment with punicalagin $(12.5,25,50,100$, and $200 \mu \mathrm{g} / \mathrm{mL})$ for $24 \mathrm{~h}$. Control represents a culture medium without punicalagin. The significance of differences between the groups was evaluated by One-way ANOVA followed by Dunnett's multiple comparison test. The data are expressed as means \pm SEM. ELISA.

\section{Effect of pomegranate peel extract on the release of steroid hormones}

Pomegranate peel extract could affect the secretion of $17 \beta$-estradiol and progesterone by the HGL5 cells. The results showed a significant increase of the 17ß-estradiol level after pomegranate peel extract supplementation at the concentrations $50(\mathrm{P} \leq 0.01), 100$, and $200(\mathrm{P} \leq 0.001) \mu \mathrm{g} / \mathrm{mL}$. Additionally, progesterone secretion was significantly affected after pomegranate peel extract treatment. The level of progesterone was significantly $(\mathrm{P} \leq 0.05)$ decreased at all used concentrations except the highest concentration of $200 \mu \mathrm{g} / \mathrm{mL}$. The results are shown in Figure 4

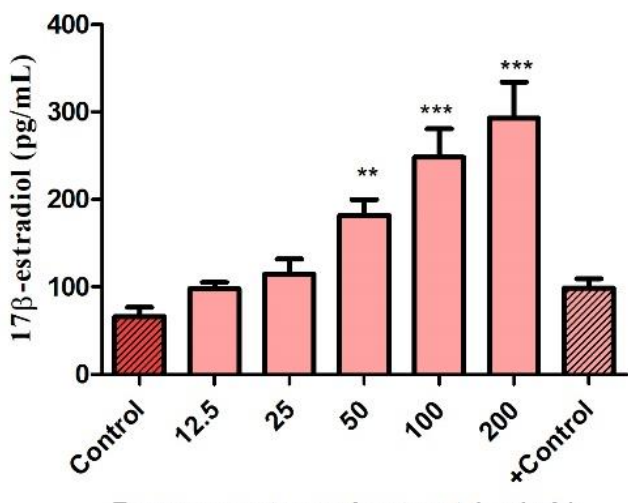

Pomegranate peel extract $(\mu \mathrm{g} / \mathrm{mL})$ 


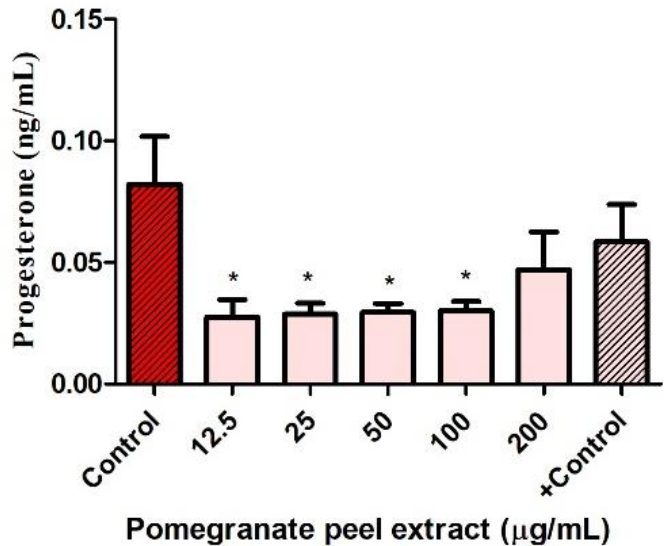

B

Figure 4 Release of $17 \beta$-estradiol (A) and progesterone (B) by HGL5 cells after treatment with pomegranate peel extract $(12.5,25,50,100$, and $200 \mu \mathrm{g} / \mathrm{mL})$ for $24 \mathrm{~h}$. Control represents a culture medium without pomegranate peel extract +Control with ethanol in an amount corresponding to the highest used concentration of extract. The significance of differences between the groups was evaluated by One-way ANOVA followed by Dunnett's multiple comparison test. The data are expressed as means \pm SEM. ELISA.

Nowadays, phytonutrients found in fruits and vegetables have been receiving increasing attention for their beneficial impacts on reproductive functions (Halenar et al., 2016; Packova et al., 2015, 2016; Roychoudhury et al., 2017, 2018, 2020; Michalcova et al., 2019; Baldovská et al., 2019, Kolesárová et al., 2020). Investigating the anti-proliferative efficiency of natural biomolecules against cancer has gained increasing momentum for designing potential chemopreventive and chemotherapeutic agents (Masaud $\boldsymbol{e t}$ al., 2014; Zhang $\boldsymbol{e t}$ al., 2020). Natural products with beneficial properties have outstanding anticancer activity with high efficiency and minimal side effects, which can induce cell senescence to suppress the occurrence and development of tumours, by inhibiting telomerase activity, triggering DNA damage, and activating or inactivating oncogenes (Liu et al., 2020). Application of pomegranate and its extracts has been extensively studied and has so far shown promising results (Kandys and Kokkinomagoulos, 2020). The present study discusses the effects of pomegranate peel extract and punicalagin, one of its main phytochemicals on human ovarian cells.

Pomegranate is a rich source of polyphenols and pomegranate extracts are known to possess strong antioxidant properties, including anti-cancer activity on in vitro cancer cell models, preclinical laboratory animals, and early phase clinical trials (Masaud et al., 2014). In the present study, the biological effects of both pomegranate peel extract and punicalagin on the human granulosa cells HGL5 and human ovarian carcinoma cells OVCAR-3 was examined. The experiments were designed to determine the effects of punicalagin and pomegranate peel extract on cell viability and the secretion of selected steroid hormones. The inhibition of proliferation of cancer cells OVCAR-3 by the pomegranate peel extract without a negative impact on healthy granulosa cells was observed. The present findings are consistent with that of a previous study indicating that natural polyphenols effectively inhibit proliferation in ovarian cancer cells (Zhang et al., 2020). The results are also in line with other recent studies which demonstrated the anti-proliferative and apoptosis-inducing effect of pomegranate peel extracts and punicalagin on prostate cancer cells (Adams et al., 2010; Adaramoye et al., 2017). In accordance with our findings, another previous study showed the cell-specific and dose-dependent anti-proliferative effect of polyphenol-rich pomegranate extract on human ovarian carcinoma cells in vitro (Baldovská et al., 2019).

By contrast, the present results also showed a significant decrease in the viability ovarian granulosa cells HGL5 after punicalagin supplementation at the highest concentration of $200 \mu \mathrm{g} / \mathrm{mL}$. Divergent findings have been reported by Packova et al. (2016), too, who described the stimulatory effect of punicalagin on the proliferation of porcine ovarian granulosa cells at concentrations $1 \mu \mathrm{g} / \mathrm{mL}$. Further carefully designed confirmatory studies on the potential roles of pomegranate and its main component punicalagin on cell proliferation are therefore needed to reveal the exact dose-response relationship and the nature of effect.

Many studies have shown that polyphenol punicalagin effectively inhibits cancer cell proliferation (Wang et al., 2013; Adaramoye et al., 2017; Yao et al., 2017; Cheng et al., 2018; Zhang et al., 2020), however, the results from our study demonstrated no significant change in the viability of ovarian cancer cells OVCAR-3. Although the mechanism of action of the pomegranate extract has not been fully established, our results from the tested parameters are in agreement with a study conducted by Masaud et al. (2014) that the pomegranate extract exerts more anti-cancer effect as compared to any of its individual constituents.
This may be due to its multiple substances, which work in tandem to produce its pharmacological activity.

Furthermore, contemporary studies have reported the anti-proliferative and anticancer activities of the pomegranate juice, extract, or oil by modulating multiple signaling pathways (Sharma et al., 2017), including the downregulation of Akt/mTOR pathway, and induction of apoptosis by increasing the Bax/Bcl-2 ratio (Syed et al., 2013). Investigations on the possible functional interrelationship between pomegranate's actions and ovarian cancer revealed that pomegranate fruit juice, ellagic acid and luteolin (phytocomponents of pomegranate) suppressed the proliferation and migration of the ovarian cancer cells and down-regulated the expression of matrix metalloproteinases MMP2 and MMP9, while ellagic acid induced a greater effect than luteolin (Liu et al., 2017). In addition, ellagic acid treatment of the human ovarian carcinoma ES-2 and PA1 cells inhibited cell proliferation with a dose- and time-dependent manner induced a decrease of cyclins D1 and E levels, and caused an increase of p53 and p21, which led to cell cycle arrest in G1 phase (Chung et al., 2013). In order to further explore the relationship between punicalagin and its biological and anticancer activities, researchers observed the induction of cellular senescence via cell cycle arrest and upregulation of p21 (Wang et al., 2013). Resveratrol derivative (3,3',4,4'-tetrahydroxy-trans-stilbene) can induce senescence and inhibit cancer cell proliferation, too, which is accompanied by increased DNA damage and ROS production, reduction of DNA damage repair capacity and decrease of activity of enzymatic antioxidants (Mikula-Pietrasik et al., 2015). In another study, the mechanism underlying the effect of isoquercitrin on human ovarian carcinoma cells OVCAR-3 was examined. Michalcova et al. (2019) concluded that the impact of isoquercitrin on ovarian carcinoma cells may be mediated by an antioxidative pathway that involves inhibition of intracellular ROS production, thereby limiting oxidative stress.

Various parts of the fruit, method of extraction, and different solvents can define the phytochemical profile of the pomegranate extracts and their biological activities (Tamborlin et al., 2020). Phytochemical characterization of pomegranate peel and seed using ultra-high-performance liquid chromatographicdiode array (UHPLC-DAD) showed a positive correlation between antioxidant capacity and total phenolic content. Additionally, the results showed that pomegranate peel possesses high phenolic (TPC: $224.39 \mathrm{mg} \mathrm{GAE} / \mathrm{g} \mathrm{dw}$ ) and flavonoid (TFC: $62.64 \mathrm{mg}$ rutin/g dw) contents and the results also showed that punicalagin $\beta(216: 36 \pm 9: 94 \mathrm{mg} / \mathrm{g})$ and punicalagin $\alpha(154: 94 \pm 5: 21 \mathrm{mg} / \mathrm{g})$ were the most abundant compounds present in pomegranate peel (Sabraoui $\boldsymbol{e} t$ al., 2020). In this context, it was previously shown that pomegranate peel could be used for the fortification of functional food products, as well as in health applications due to its higher antioxidant activity.

Pomegranate's phytonutrients may play an important role as the possible modulator of process of steroidogenesis (Packova et al., 2015; Baldovská $\boldsymbol{e t}$ al. 2019). Polyphenols found in the pomegranate peel and pomegranate juice, especially flavonoids (e.g., flavonols, flavones, and anthocyanidins), and hydrolysable tannins (e.g., ellagitannins and gallotannins) have been hypothesized to reduce breast cancer risk through modulation of sex hormones (Kapoor et al., 2015), and pomegranate ellagitannin-derived compounds may modulate estrogen synthesis by inhibition of aromatase activity (Kim $\boldsymbol{e t}$ al., 2002; Adams et al., 2010).

Similarly, Modaeinama et al. (2015) examined the anti-cancer properties of a methanolic pomegranate peel extract on different human cancer cells Interestingly, the most responsive cells to the anti-proliferative effect were breast adenocarcinoma cells MCF-7, whereas ovarian cancer cells SKOV3 were the least responsive cells in comparison to the other monitored cancer cells. Different responsiveness of cells to the anti-proliferative effect of pomegranate could be explained by the hormone-sensitivity of cancer type and pomegranate's polyphenols could interfere with aromatase activity and so hinder estrogen synthesis which can act as a growth factor of cells.

Clinical studies suggest polyphenolic compounds may exert breast cancerpreventive effects through modulation of endogenous sex hormone levels. Beneficial effects of pomegranate juice consumption on hormonal biomarkers of breast cancer risk, including estradiol, estrone, testosterone, androstenedione, and sex hormone binding globulin (SHBG) was investigated (Kapoor et al., 2015). In fact, the proliferative or anti-proliferative effects induced by $17 \beta$-estradiol in cancer cells are mediated by two different isoforms of the estrogen receptors, $\mathrm{ER} \alpha$ and ER $\beta$. 17 $\beta$-estradiol via ER $\alpha$ evokes rapid signals to induce proliferation in breast cancer cells, while $17 \beta$-estradiol-induces ER $\beta$ rapid signaling that inhibits proliferation of colon cancer cells. These contrasting effects could be associated with the molecular complexity of the 17ß-estradiol-induced intracellular signaling pathway triggered by the estrogen receptors (Acconcia and Marino, 2011). It was shown that ellagic acid present in pomegranate is able to modulate the activity of the estrogen receptor subtypes ER $\alpha$ and ER $\beta$ in HeLa cells (Papoutsi et al., 2005)

Based on accumulating experimental evidence, there is reason to hypothesize that pomegranate peel extract and punicalagin may alter the secretion of steroid hormones. This in vitro study was carried out to reveal pomegranate's potential in the modulation of secretion of steroid hormones by human ovarian granulosa cells HGL5, too. We evaluated the impact of punicalagin on the secretion of $17 \beta$ estradiol and progesterone. Punicalagin treatment at selected concentrations 
increased $17 \beta$-estradiol levels but did not significantly affect progesterone secretion, so punicalagin may be an effector in the process of ovarian steroidogenesis. However, divergent findings have been reported for the response of rabbit ovarian fragments on punicalagin treatment, whereas punicalagin (at $100 \mathrm{mg} / \mathrm{mL}$ ) increased progesterone levels and the secretion of $17 \beta$-estradiol were significantly decreased by the concentration of punicalagin $10 \mathrm{mg} / \mathrm{mL}$ (Packova et al., 2015). Regarding the effect of pomegranate peel extract supplementation on the tested parameters, we observed significant increase of $17 \beta$-estradiol secretion. Our results also demonstrated that progesterone levels were decreased after pomegranate peel extract treatment. The present findings are consistent with previous studies indicating that pomegranate extract can modulate the secretion of steroid hormone 17 $\beta$-estradiol in human granulosa cells (Baldovská et al., 2019).

Following previous studies, our data confirm that pomegranate fruit is a unique source of phytoestrogens and divergent cellular effects on HGL5 and OVCAR-3 cells could be associated with the modulative activity of pomegranate peel extract on steroidogenesis. Finally, identification of the mechanisms that are associated with the previously mentioned activities of pomegranate and its compound punicalagin as well as its possible synergistic effects with other phytocompounds are essential for future food applications and further nutraceutical product development with potential health benefits. Therefore, more evidence is needed to clarify the effect of punicalagin and pomegranate peel on human health.

\section{CONCLUSION}

In conclusion, phytochemicals present in functional foods offer great hope as an alternative therapy for many disorders. The present study examined the potential modulatory effect of punicalagin and pomegranate peel extract from non-edible parts of Punica granatum L. We tested the anti-proliferative effect as well as the effect on the release of steroid hormones by using non-cancerous and cancerous human ovarian cells lines in vitro. We suggested that pomegranate peel extract used in this study may contain bioactive compounds, which exert antiproliferative effects in a cell-dependent manner. It can be indicated that the polyphenol punicalagin and pomegranate peel extract may be a potential endocrine modulator of steroidogenesis in ovarian cells HGL5. Thus, pomegranate peel extract seems to be a better chemopreventive agent in comparison to pure punicalagin, however, further carefully designed studies involving other pomegranate compounds are necessary to reveal their possible anti-cancer activities and the exact dose-response relationships.

Acknowledgements: This work was supported by the Ministry of Education, Science, Research and Sport of the Slovak Republic projects APVV-18-0312, DS-FR-19-0049, VEGA 1/0266/20, The Excellent scientific team "Center of Animal Reproduction (CeRA)", the Operational Program Integrated Infrastructure within the project: Demand-driven research for the sustainable and inovative food, Drive4SIFood 313011V336, cofinanced by the European Regional Development Fund, and AgroBioTech Research Centre built in accordance with the project Building „AgroBioTech" Research Centre ITMS 26220220180 .

\section{REFERENCES}

ACCONCIA, F., MARINO, M. 2011. The Effects of 17ß-estradiol in Cancer are Mediated by Estrogen Receptor Signaling at the Plasma Membrane. Frontiers in physiology, 2: 30. https://doi.org/10.3389/fphys.2011.00030.

ADAMS, L. S., ZHANG, Y., SEERAM, N. P., HEBER, D., CHEN, S. 2010 Pomegranate ellagitannin-derived compounds exhibit antiproliferative and antiaromatase activity in breast cancer cells in vitro. Cancer Prevention Research, 3(1), 108-113. https://doi.org/10.1158/1940-6207.capr-08-0225.

ADARAMOYE, O., EFQUEN, B., NITZSCHE, B., HÖPFNER, M., JUNG, K. RABIEN, A. 2017. Punicalagin, a polyphenol from pomegranate fruit, induces growth inhibition and apoptosis in human PC-3 and LNCaP cells. ChemicoBiological Interaction, 274, 100-106. https://doi.org/10.1016/j.cbi.2017.07.009.

AL-MUAMMAR, M. N., KHAN, F. 2012. Obesity: The preventive role of the pomegranate (Punica granatum). Nutrition, 28, 595-604. https://doi.org/10.1016/j.nut.2011.11.013.

BALDOVSKÁ, S., MICHALCOVÁ, K., HALENÁR, M., CARBONELLBARRACHINA, A.A., KOLESÁROVÁ, A. 2019. Polyphenol-rich pomegranate extract as a potential modulator of steroidogenesis in human ovarian cells Journal of Microbiology and Biotechnology and Food Science, 8, 1343-1346. https://doi.org/10.15414/jmbfs.2019.8.6.1343-1346.

BANNERMAN, D. D., TUPPER, J. C., RICKETTS, W. A., BENNETT, C. F., WINN, R. K., HARLAN, J. M. 2001. A constitutive cytoprotective pathway protects endothelial cells from lipopolysaccharide-induced apoptosis. Journal of Biological Chemistry, $276 \quad$ (18), $\quad 14924-14932$ https://doi.org/10.1074/jbc.m100819200.

CERDA, B., LLORACH, R., CERON, J.J., ESPIN, J.C., TOMAS-BARBERAN F.A. 2003. Evaluation of the bioavailability and metabolism in the rat of punicalagin, an antioxidant polyphenol from pomegranate juice. European Journal of Nutrition. 42, 18-28. https://doi.org/10.1007/s00394-003-0396-4.
CHENG, X., YAO, X., XU, S., PAN, J., YU, H., BAO, J., GUAN, H., LU, R. ZHANG, L. 2018. Punicalagin induces senescent growth arrest in human papillary thyroid carcinoma BCPAP cells via NF-kappa B signaling pathway. Biomedicine \& Pharmacotherapy, 103, 490-498. https://doi.org/10.1016/j.biopha.2018.04.074

CHOI, D. W., KIM, J. Y., CHOI, S. H., JUNG, H. S., KIM, H. J., CHO, S. Y., KANG, C. S., CHANG, S. Y. 2006. Identification of steroid hormones in pomegranate (Punica granatum) using HPLC and GC-mass spectrometry. Food Chemistry, 96(4), 562-571. https://doi.org/10.1016/j.foodchem.20 05.03.010.

CHUNG, Y.C., LU, L.C., TSAI, M.H., CHEN, Y.J., CHEN, Y.Y, YAO, S.P., HSU, C.P. 2013. The inhibitory effect of ellagic Acid on cell growth of ovarian carcinoma cells. Evidence-Based Complementary and Alternative Medicine, 2013:306705. https://doi.org/10.1155/2013/306705.

DEROO, B.J., KORACH, K.S. 2006. Estrogen receptors and human disease. The Journal of Clinical Investigation, 116(3): 561570.https://doi.org/10.1172/JCI27987.

EL-MISSIRY, M.A., AMER, M.A., HEMIEDA, F.A.E., OTHMAN, A.I., SAKR, D.A., ABDULHADI, H.L. 2015.Cardioameliorative effect of punicalagin against streptozotocin-induced apoptosis, redox imbalance, metabolic changes and inflammation. Egyptian Journal of Basic and Applied Sciences, 2, 247-260. https://doi.org/10.1016/j.ejbas.2015.09.004.

GONZALEZ-TRUJANO, M. E., PELLICER, F., MENA, P., MORENO, D. A., GARCÍA-VIGUERA, C. 2015. Antinociceptive and anti-inflammatory activities of a pomegranate (Punica granatum L.) extract rich in ellagitannins. International Journal of Food Sciences and Nutrition, 66(4), 395399. https://doi.org/10.3109/09637486.2015.1024208.

HALENAR, M., KOVACIKOVA, E., NYNCA, A., SADOWSKA, A. 2016 Stimulatory effect of amygdalin on the viability and steroid hormone secretion by porcine ovarian granulosa cells in vitro. Journal of Microbiology and Biotechnology and Food Science, 5 (Special 1), 44-46. https://doi.org/10.15414/jmbfs.2016.5.special1.44-46.

KANDYLIS, P., KOKKINOMAGOULOS, E. 2020. Food Applications and Potential Health Benefits of Pomegranate and its Derivatives. Foods, 9(2), 122 https://doi.org/10.3390/foods9020122.

KAPOOR, R., RONNENBERG, A., PULEO, E., CHATTERTON, R.T. JR, DORGAN, J.F., SEERAM, N.P., STURGEON, S.R. 2015. Effects of pomegranate juice on hormonal biomarkers of breast Cancer risk. Nutrition and Cancer, 67(7):1113-1119. https://doi.org/10.1080/01635581.2015.1073756.

KIM, N. D., MEHTA, R., YU, W., NEEMAN, I., LIVNEY, T., AMICHAY, A., POIRIER, D., NICHOLLS, P., KIRBY, A., et al. 2002. Chemopreventive and adjuvant therapeutic potential of pomegranate (Punica granatum) for human breast cancer. Breast Cancer Research and Treatment, 71(3), 203-217. https://doi.org/10.1023/A:1014405730585.

KOLESÁROVÁ, A., DŽURŇÁKOVÁ, V., MICHALCOVÁ, K. BALDOVSKÁ, S., CHRASTINOVÁ, L., ONDRUŠKA, L., JURČÍK, R., TOKÁROVÁ, K., KOVÁČIKOVÁ, E., KOVÁČIK, A., MASSÁNYI, P. 2020. The effect of apricot seeds on microscopic structure of rabbit liver. Journal of Microbiology and Biotechnology and Food Science, 10, 321-324 https://doi.org/10.15414/jmbfs.2020.10.2.321-324.

KOLESAROVA, A., SIROTKIN, A. V., MELLEN, M., ROYCHOUDHURY, S. 2015. Possible intracellular regulators of female sexual maturation. Physiological research, 64, 379-386. ISSN 0862-8408.

LIU, H., ZENG, Z. WANG, S., LI, T., MASTRIANI, E., LI, Q.H., BAO, H.X., ZHOU, Y.J., WANG, X., LIU, Y., LIU, W., HU, S., GAO, S., YU, M., QI, Y. SHEN, Z., WANG, H., GAO, T., DONG, L., JOHNSTON, R.N., LIU, S.L. 2017. Main components of pomegranate, ellagic acid and luteolin, inhibit metastasis of ovarian cancer by down-regulating MMP2 and MMP9. Cancer Biology \& Therapy, 18(12), 990-999. https://doi.org/10.1080/15384047.2017.1394542.

LIU, Y., YANG, S., WANG, K., LU, J., BAO, X., WANG, R., QIU, Y., WANG, T., YU, H. 2020. Cellular senescence and cancer: Focusing on traditional Chinese medicine and natural products. Cell Proliferation, 53(10), e12894. https://doi.org/10.1111/cpr.12894.

MASAUD, I.A., ROHIN, M.A.K., BAIG, A.A., MOHAMAD, N. 2014. Determination of Punicalagins Content, Metal Chelating, and Antioxidan Properties of Edible Pomegranate (Punica granatum L) Peels and Seeds Grown in Morocco. Journal of Chemical and Pharmaceutical Research, 6(11):427-433. MIKULA-PIETRASIK, J., SOSINSKA, P., MURIAS, M., WIERZCHOWSKI, M., BREWINSKA-OLCHOWIK, M., PIWOCKA, K., SZPUREK, D., KSIAZE, K. 2015. High Potency of a Novel Resveratrol Derivative, 3,30,4,40 Tetrahydroxytrans-

stilbene, against Ovarian Cancer Is Associated with an Oxidative Stress-Mediated Imbalance between DNA Damage Accumulation and Repair. Oxidative Medicine and Cellular Longevity, 2015, 135691. https://doi.org/10.1155/2015/135691. MICHALCOVA, K., ROYCHOUDHURY, S., HALENAR, M., TVRDA, E., KOVACIKOVA, E., VASICEK, J., CHRENEK, P., BALDOVSKA, S., SANISLO, L., KREN, V., KOLESAROVA, A. 2019. In vitro response of human ovarian cancer cells to dietary bioflavonoid isoquercitrin. Journal of Environmental Science and Health, Part B, 54, 752-757. https://doi.org/10.1080/03601234.2019.1633214. 
MODAEINAMA, S., ABASI, M., ABBASI, M.M., JAHANBAN-ESFAHLAN, R. 2015. Anti Tumoral Properties of Punica Granatum (Pomegranate) Peel Extract on Different Human Cancer Cells. Asian Pacific Journal of Cancer Prevention, 16(14):5697-5701. https://doi.org/10.7314/apjcp.2015.16.14.5697. PACKOVA, D., CARBONELL-BARRACHINA, A. A., KOLESAROVA, A. 2015. Ellagitannins - compounds from pomegranate as possible effector in steroidogenesis of rabbit ovaries. Physiological Research, 64, 583-585. ISSN 0862-8408.

PACKOVA, D., KOLESAROVA, A. 2016. Do punicalagins have possible impact on secretion of steroid hormones by porcine ovarian granulosa cells? Journal of Microbiology, Biotechnology and Food Sciences, 5, 57-59. https://doi.org/10.15414/jmbfs.2016.5.special1.57-59.

PAPOUTSI, Z., KASSI, E., TSIAPARA, A., FOKIALAKIS, N., CHROUSOS, G. P., MOUTSATSOU, P. 2005. Evaluation of estrogenic/antiestrogenic activity of ellagic acid via the estrogen receptor subtypes ER $\alpha$ and ER $\beta$. Journal of Agricultural and Food Chemistry, 53(20), 7715-7720. https://doi.org/10.1021/jf0510539.

ROYCHOUDHURY, S., AGARWAL, A., VIRK, G., CHO, C.L. 2017. Potential role of green tea catechins in the management of oxidative stress-associate infertility. Reproductive Biomedicine Online, 34(5), 487-498. https://doi.org/10.1016/j.rbmo.2017.02.006.

ROYCHOUDHURY, S., HALENAR, M., MICHALCOVA, K., NATH, S., KACANIOVA, M., KOLESAROVA, A. 2018. Green tea extract affects porcine ovarian cell apoptosis. Reproductive Biology, 18(1), 94-98. https://doi.org/10.1016/j.repbio.2018.01.007.

ROYCHOUDHURY, S., CHAKRABORTY, S., DAS, A., GUHA, P., AGARWAL, A., HENKEL, R. 2020. Herbal medicine use to treat andrological problems: Asian and Indian subcontinent: Ginkgo biloba, Curcuma longa, and Camellia sinensis. In Herbal Medicine in Andrology, Eds. Henkel, R. and Agarwal, A, 2020, Academic Press, Elsevier, in press. ISBN 9780128155653.

SABRAOUI, T., KHIDER, T., NASSER, B., EDDOHA, R., MOUIAHID, A., BENBACHIR, M., ESSAMADI, A. 2020. Determination of Punicalagins Content, Metal Chelating, and Antioxidant Properties of Edible Pomegranate (Punica granatum L) Peels and Seeds Grown in Morocco. International Journal of Food Science, 2020, 8. https://doi.org/10.1155/2020/8885889.

SEERAM, N. P., ADAMS, L. S., HENNING, S. M., NIU, Y., ZHANG, Y., NAIR, M. G., HEBER, D. 2005. In vitro anti-proliferative, apoptotic and antioxidant activities of punicalagin, ellagic acid and a total pomegranate tannin extract are enhanced in combination with other polyphenols as found in pomegranate juice. Journal of Nutritional Biochemistry, 16(6), 360-367. https://doi.org/10.1016/j.jnutbio.2005.01.006.

SHARMA, P., SARAH, F. C., AFAQ, F. 2017. Pomegranate for prevention and treatment of cancer: An update. Molecules, 22(1), 177. https://doi.org/10.3390/molecules22010177.

SIEGEL, R.L., MILLER, K.D., JEMAL, A. 2018. Cancer statistics. CA: A Cancer Journal for Clinicians, 68, 7-30. https://doi.org/10.3322/caac.21442.

SINGH, M., JHA, A., KUMAR, A., HETTIARACHCHY, N., RAI, A. K. 2014 Influence of the solvents on the extraction of major phenolic compounds (punicalagin, ellagic acid and gallic acid) and their antioxidant activities in pomegranate aril. Journal of Food Science and Technology, 51(9), 2070-2077. https://doi.org/10.1007/s13197-014-1267-0.

SYED, N. D., CHAMCHEU, J. C., ADHAMI, V. M., MUKHTAR, H. 2013. Pomegranate extracts and cancer prevention: Molecular and cellular activities. Anti-cancer Agents in Medicinal Chemistry, 13(8), 11491161. https://doi.org/10.2174/1871520611313080003.

TAMBORLIN, L., SUMERE, B.R., DE SOUZA, M.C., PESTANA, N.F., AGUIAR, A.C., EBERLIN, M.N., SIMABUCO, F.M., ROSTAGNO, M.A., LUCHESSI, A.D. 2020. Characterization of pomegranate peel extracts obtained using different solvents and their effects on cell cycle and apoptosis in leukemia cells. Food Science \& Nutrition, 8(10), 5483-5496. https://doi.org/10.1002/fsn3.1831.

VIUDA-MARTOS, M., FERNANDEZ-LOPEZ, J., PEREZ-ALVAREZ, J. A 2010. Pomegranate and its Many Functional Components as Related to Human Health: A Review. Comprehensive Reviews in Food Science and Food Safety, 9(6), 635-654. https://doi.org/10.1111/j.1541-4337.2010.00131.x.

WANG, S.G., HUANG, M.H., LI, J.H., LAI, F.I., LEE, H.M., HSU, Y.N. 2013 Punicalagin induces apoptotic and autophagic cell death in human U87MG glioma cells. Acta Pharmacologica Sinica, 34(11), 1411-1419. https://doi.org/10.1038/aps.2013.98.

YAIDIKAR, L., THAKUR, S. 2015. Punicalagin attenuated cerebral ischemiareperfusion insult via inhibition of proinflammatory cytokines, up-regulation of Bcl-2, down-regulation of Bax, and caspase-3. Molecular and Cellular Biochemistry, 402, 141-148. https://doi.org/10.1007/s11010-014-2321-y.

YAO, X., CHENG, X., ZHANG, L., YU, H., BAO, J., GUAN, H., LU, R. 2017.Punicalagin from pomegranate promotes human papillary thyroid carcinoma BCPAP cell death by triggering ATM-mediated DNA damage response. Nutrition Research, 47, 63-71. https://doi.org/10.1016/j.nutres.2017.09.001.
YUAN, T., MA, H., LIU, W., NIESEN, D. B., SHAH, N., CREWS, R., ROSE, K. N., VATTEM, D. A, SEERAM, N. P. 2016. Pomegranate's Neuroprotective Effects against Alzheimer's Disease Are Mediated by Urolithins, Its EllagitanninGut Microbial Derived Metabolites. ACS Chemical Neuroscience, 7(1), 26-33. https://doi.org/10.1021/acschemneuro.5b00260.

ZHANG, L., CHINNATHAMBI, A., ALHARBI, A.S., VEERARAGHAVAN, V.P., MOHAN, S.K., ZHANG, G. 2020.Punicalagin promotes the apoptosis in human cervical cancer (ME-180) cells through mitochondrial pathway and by inhibiting the NF-kB signaling pathway. Saudi Journal of Biological Sciences, 27(4), 1100-1106. https://doi.org/10.1016/j.sjbs.2020.02.015.

ZHOU, B., WAN, Y., CHEN, R., ZHANG, C., LI, X., MENG, F., GLASER, S., WU, N., ZHOU, T., LI, S., FRANCIS, H., ALPINI, G., ZOU, P. 2020. The emerging role of cellular senescence in renal diseases. Journal of Cellular and Molecular Medicine, 24(3), 2087-2097. https://doi.org/10.1111/jcmm.14952.

ZHOU, Y., LI, Y., ZHOU, T., ZHENG, J., LI, S., LI, H.B. 2016. Dietary Natural Products for Prevention and Treatment of Liver Cancer. Nutrients, 8, 156.https://doi.org/10.3390/nu8030156. 